\title{
Israeli Settlements, U.S. Foreign Policy, and International Law
}

\author{
VICTOR KATTAN \\ Middle East Institute, National University of Singapore, Singapore \\ ORCID No: 0000-0001-5109-5933
}

\begin{abstract}
U.S. Secretary of State Mike Pompeo's statement that Israel's settlements are not contrary to international law caused international outrage as it marked a dramatic departure from previous U.S. statements on the legality of Israel's West Bank settlements. This paper argues that the announcement was connected to developments at the International Criminal Court (ICC) where the Prosecutor, a month later, announced that there is a reasonable basis to initiate an investigation into alleged war crimes committed in Palestine by Israel and Hamas.
\end{abstract}

Keywords: Israeli-Palestinain Conflict, Settlements, West Bank, United States, International Criminal Court 


\section{Introduction}

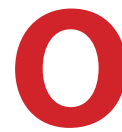
n November 18, 2019, U.S. Secretary of State Mike Pompeo announced that "The establishment of Israeli civilian settlements in the West Bank is not per se inconsistent with international law." ${ }^{1}$ The statement caused international outrage as it marked a dramatic departure from previous U.S. statements on the legality of Israel's West Bank settlements going back decades, and was widely seen as a political gift from one politician mired in legal trouble to another. ${ }^{2}$ Israel's settlements have long been considered contrary to international law as they violate Article 49, paragraph 6 , of the Fourth Geneva (Civilians) Convention (1949), according to which "The Occupying Power shall not deport or transfer parts of its own civilian population into the territory it occupies."3

The U.S. legal position on the legality of Israel's settlement was publicly articulated in a State Department legal opinion from 1978, which concluded that the settlements established in the territories occupied by Israel in June 1967, which included East Jerusalem, ${ }^{4}$ were "inconsistent with international law." ${ }^{5}$ However, this was not the first time the U.S. condemned Israel's settlements publicly. United Nations Security Council (UNSC) Resolution 298, adopted during the Nixon Administration, ${ }^{6}$ criticized the "transfer of populations" into the occupied section of the "City of Jerusalem," as early as 1971. This is important to empha- size, given that the Trump Administration has presented the issue of Israeli settlements as a "partisan" issue associated with the Democratic Party, when in fact both Republican and Democratic administrations had consistently opposed them. ${ }^{7}$ The legal position outlined by the State Department in 1978 was subsequently endorsed by the UNSC in a number of resolutions which reaffirmed that Israel is the occupying power in East Jerusalem, the West Bank, and the Gaza Strip. ${ }^{8}$ Consistent with these UNSC resolutions, the International Court of Justice (ICJ), the principal judicial organ of the United Nations (UN), concluded in paragraph 120 of its 2004 Wall opinion that "the Israeli settlements in the Occupied Palestinian Territory (including East Jerusalem) have been established in breach of international law."

Given the virtual unanimity of legal opinion on the illegality of Israel's settlements in all of the territories occupied by Israel over many decades, it is not surprising that Pompeo's statement was widely criticized, not only by the Palestinian leadership, ${ }^{10}$ but also by close allies of the United States including Canada ${ }^{11}$ and the United Kingdom. ${ }^{12}$ An omnibus resolution adopted in December by an overwhelming majority of members of the UN General Assembly affirmed that Israel remains the occupying power in East Jerusalem, the West Bank, and the Gaza Strip. ${ }^{13}$

\section{What about East Jerusalem?}

Pompeo's statement only referred to Israeli settlements in the West Bank. 
Since no legal opinion has been published by the Trump Administration justifying the change of policy, it is difficult to assess whether the reference to the West Bank included East Jerusalem in the U.S. view. ${ }^{14}$ Prior to President Trump's statement on Jerusalem in December 2017, ${ }^{15}$ the U.S. position was that East Jerusalem was part of the West Bank; that is, territory occupied by Israel in the 1967 war. $^{16}$ As former U.S. Secretary of State John Kerry explained, "every U.S. administration since 1967, along with the entire international community, has recognized East Jerusalem as among the territories that Israel occupied in the Six-Day War."17 However, this no longer appears to be U.S. policy. Notably, the so-called "Deal of the Century" proposed establishing a Palestinian capital in Abu Dis, which is a Palestinian town located outside the Old City of Jerusalem. ${ }^{18}$

\section{The Significance of the Timing of Pompeo's Announcement}

The timing of Pompeo's announcement on the settlements was intriguing: the new policy was announced three days after the U.S. deadline for the submission of its counter-memorial to the ICJ in Palestine v. United States of America, in which Palestine is challenging the legality of the Trump Administration's decision to move the U.S. embassy from Tel Aviv to Jerusalem. ${ }^{19}$ The case could be significant, as the Court might say something about the status of the territories occupied by Israel since 1967 and whether a Palestinian state exists

\section{Not only is there a near-}

consensus of legal opinion that the establishment of settlements in the West Bank is unlawful, Pompeo's statement notwithstanding, but their illegality has reached the courts whose decisions could have detrimental economic consequences for Israel's settlement enterprise

where Israel has established over two hundred settlements in East Jerusalem and the West Bank. ${ }^{20}$

The announcement by Pompeo also came a week after the European Court of Justice decided that Israel's presence in the West Bank was that of "an occupying power" and "not ... a sovereign entity" in a case on the mislabeling of settlement products in the European Union. ${ }^{21}$

In other words, not only is there a near-consensus of legal opinion that the establishment of settlements in the West Bank is unlawful, Pompeo's statement notwithstanding, but their illegality has reached the courts whose decisions could have detrimental economic consequences for Israel's settlement enterprise. This is especially significant as there are concerns in Israel that consumers may begin to exercise a measure of 


\section{But even if the Prosecutor}

were to take a restrictive

view, and only look at Israel's

settlement activities after

2015, it is well documented

that the Israeli government

has accelerated its settlement

activities in the last five years

discretion on ethical grounds in deciding whether to purchase products labeled as originating from Israeli settlements in the West Bank.

\section{Israel's Settlement Policy Is a Crime Under the Rome Statute}

There is a further, even more alarming problem for supporters of Israel's settlement enterprise: the preliminary examination being undertaken by the Prosecutor of the International Criminal Court (ICC) into the situation in Palestine. ${ }^{22}$ This is because Israel's settlement's policy is considered a crime under Article 8(2)(b)(viii) of the Rome Statute of the ICC.

In January 2019, The Jerusalem Post published an article on the efforts of the Zionist Organization of America (ZOA) to persuade Congress and the U.S. State Department "to rescind its famous 41-year old legal opinion that West Bank settlements are inconsistent with international law." ${ }^{23}$ This was a reference to the State De- partment's 1978 legal opinion. According to the Post, the head of the ZOA was concerned that the legal opinion "could be the basis of any potential war crimes suit in front of the International Criminal Court at The Hague with respect to settlement activity." ${ }^{24}$

As the representative arm of the World Zionist Organization (WZO) in the United States, the ZOA appears to have been acting at the behest of the Israeli government in seeking to overturn U.S. policy toward the settlements by meeting with Trump Administration officials. ${ }^{25}$ According to an official Israeli government report from 2005, ${ }^{26}$ and another government report from 2012, ${ }^{27}$ the authorities involved in the settlement's planning and construction include "the Settlement Division of the World Zionist Organization." According to B'Tselem, an Israeli human rights group, the WZO's Settlement Divi$\operatorname{sion}^{28}$ is comprised of "an equal number of ministers from the relevant government ministries and members of the WZO Executive." ${ }^{29}$ In 2013, the report of the Human Rights Council's independent international fact-finding mission to investigate Israeli settlements, described the WZO as a "Quasi-governmental organization, funded by the Government," which was also responsible for providing "funds to the settlements." ${ }^{30}$ Accordingly, the close connections between the Israeli government and the WZO Settlement Division, which are both involved in the West Bank settlement enterprise, could expose them to investigation at the ICC. 


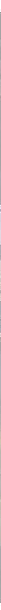

Although the ICC only has jurisdiction to examine settlement activities undertaken in Palestine's territory since April 1, 2015 (when Palestine's accession to the Rome Statute entered into force), the Prosecutor would be able to consider Israel's settlement activities before that date if she concludes that it amounts to an ongoing crime. But even if the Prosecutor were to take a restrictive view, and only look at Israel's settlement activities after 2015, it is well documented that the Israeli government has accelerated its settlement activities in the last five years. ${ }^{31}$ Indeed, in the last year alone, data shows the highest first-quarter spending on settlements in a decade. ${ }^{32}$

\section{The Settlement Regulation Law}

In 2017, the Netanyahu government supported the adoption of the Settlement Regulation Law, which aims to "legalize" Israeli settlements built on private Palestinian land by way of retroactive expropriation. ${ }^{33}$ Article 1 of the Regulation Law makes it clear that its primary objective is "to regulate Israeli settlement in Judea and Samaria [the West Bank] and to allow its continued establishment and development" (emphasis added). ${ }^{34}$ The law appears to have endorsed the controversial findings of the 2012 Levy report, ${ }^{35}$ which recommended, inter alia, that security legislation be amended to enable Israelis to purchase West Bank land directly, rather than through a corporation registered in the territory. Prior to making this recommendation, the report concluded that "the provisions of the 1949 Fourth Geneva Convention, regarding transfer of populations, cannot be considered applicable, and were never intended to apply to the type of settlement activity carried out by Israel in Judea and Samaria." ${ }^{36}$

The Settlement Regulation Law aims to facilitate the annexation of occupied territory and would therefore appear to fall squarely within the Rome
Palestinian and Israeli demonstrators, protesting against U.S. President Donald Trump's Middle East plan, in West Bank and Tel Aviv, February 2020.

JAAFAR ASHTIYEH / AFP via Getty Images

MOSTAFA ALKHAROUF / AA Photo 
The settlements are a problem for Israel at the ICC, as the Israel Supreme Court has never ruled on the legality under international law of settlements built on public land in the West Bank, for justiciability reasons, as Israeli law does not prohibit them
Israeli leaders for their involvement in decisions concerning settlement construction." Despite knowing that the Prosecutor was looking into the potential of criminal liability regarding the settlements, a few days later Netanyahu supported the first vote in favor of the bill, which became law on February 6, 2017.39

\section{Why the Settlements Are a Problem for Benjamin Netanyahu}

The realization that the illegality of the settlements could have serious consequences for the Israeli government and for its affiliated agencies and organs involved in planning and construction, following the adoption of UNSC Resolution 2334, appears to have spurred the Israeli government into action. It was reported that a special task force was set up by the U.S. Ambassador to Israel David Friedman and lawyers from the State Department, who held consultations with several Israeli officials, including Tal Becker, the legal adviser of Israel's Foreign Ministry, as well as members from the Kohelet Policy forum, a right wing think tank that is said to be close to the government. ${ }^{40} \mathrm{Ac}$ cording to reports, the White House gave Pompeo a free hand to draft the new policy, which was formulated after the State Department's legal team presented Pompeo with a 40-page legal position. ${ }^{41}$ Given the close relationship between Friedman and the settler lobby, which explicitly called for applying Israeli building and construction laws to the West Bank without needing approval from Is- 
rael's Civil Administration, ${ }^{42}$ the "repudiation" of the State Department's 1978 legal opinion by the Secretary of State was in all likelihood connected to events at the Prosecutor's Office at the ICC, which a few weeks later published a document setting out its conclusion that there is a reasonable basis to initiate an investigation into the situation in Palestine, including the issue of Israeli settlements established on the territory of Palestine, which includes East Jerusalem, the West Bank, and the Gaza Strip. ${ }^{43}$ Perhaps the settler lobby hoped that the public articulation of this revised legal opinion combined with the aggressive stance of the Trump Administration toward the ICC in general $^{44}$ and Trump's robust support for Netanyahu, would deter the Prosecutor from taking further steps. If this was their strategy, it appears to have backfired, as it did not deter the ICC Prosecutor from pressing ahead with her preliminary investigation. Significantly, eight pages of the Prosecutor's report were devoted to the settlements. ${ }^{45}$

The settlements are a problem for Israel at the ICC, as the Israel Supreme Court has never ruled on the legality under international law of settlements built on public land in the West Bank, for justiciability reasons, as Israeli law does not prohibit them. ${ }^{46}$ In fact, the current Israeli government has gone so far as to claim that the settlements are lawful, having published a document justifying this claim on the website of the Israel Ministry of Foreign Affairs. ${ }^{47}$ In the document, the Israeli Govern- ment appears to have advanced a sovereign claim to the West Bank for the first time. Therefore, for most of the settlements, there can be no question of "complementarity" in the ICC's consideration of whether Palestine's case is admissible under Article 17 of the Rome Statute, as Israel's courts do not appear to be willing or able to prosecute the crime. In other words, there is no legal obstacle preventing the ICC from exercising jurisdiction over the settlements.

\section{Conclusion}

The matter of Israeli settlements is now in the hands of the ICC Prosecutor, who has requested Pre-Trial Chamber 1 to rule on the scope of the Court's territorial jurisdiction in the situation in Palestine and to confirm that the "territory" over which the Court may exercise its jurisdiction under the ICC Statute comprises the West Bank, including East Jerusalem and the Gaza Strip. ${ }^{48}$ The Prosecutor has asked the Pre-Trial Chamber to issue its ruling within 120 days. It remains to be seen whether the government of Israel will make an appearance before the Pre-Trial Chamber or whether it will rely on the submissions made by a number of amicus curiae to the Chamber, some of whom previously worked for the Israeli government. ${ }^{49}$ On the same day the ICC Prosecutor made public its report, Israel's Attorney General published a document which claimed that:

a sovereign Palestinian state does not exist... sovereignty over the West 


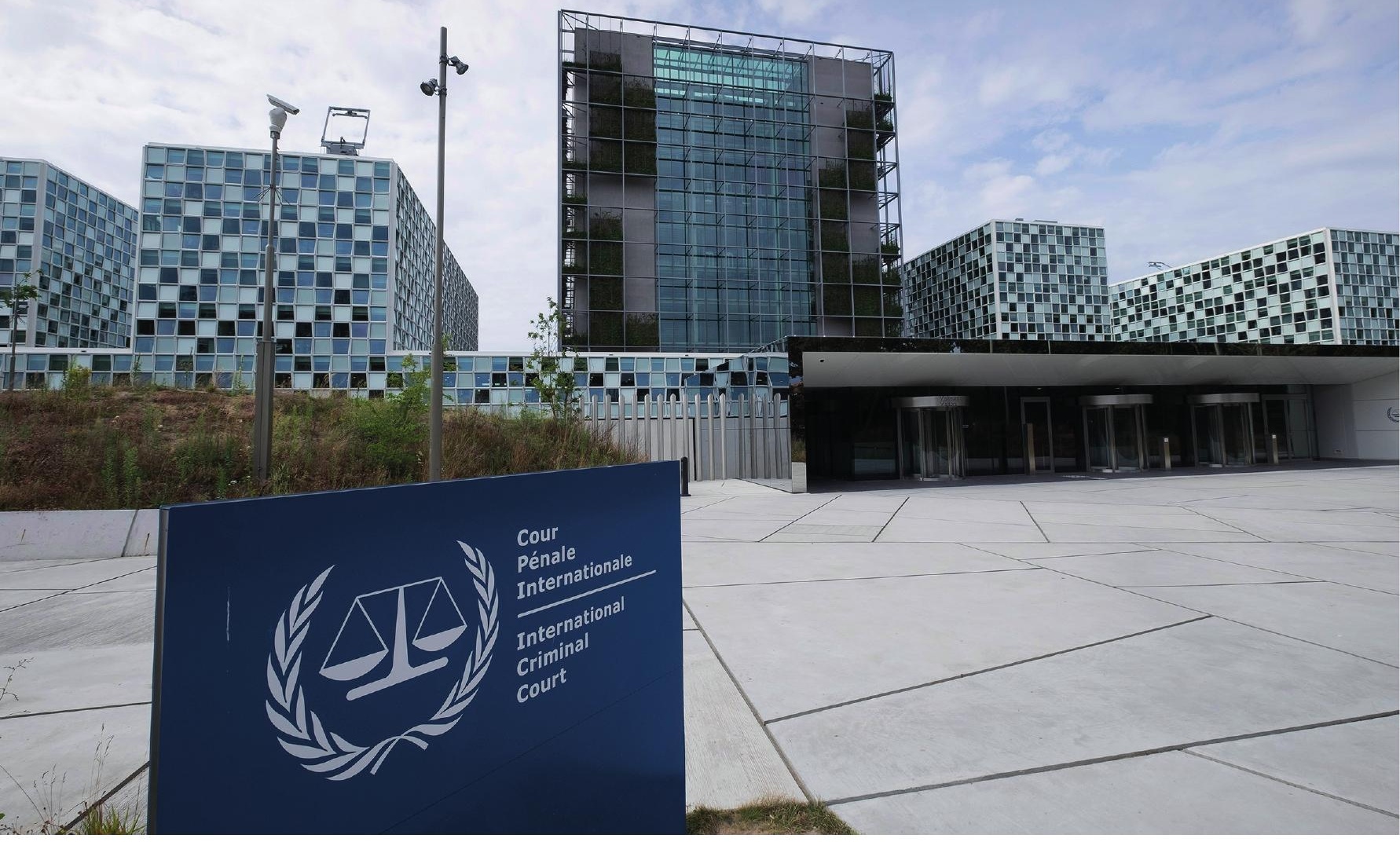

The International

Criminal Court investigates war crimes committed in Palestine by

Israel.

MICHEL PORRO Getty Images
Bank and the Gaza Strip remain in abeyance... the Palestinian entity manifestly fails to meet the criteria for statehood under general international law... The alleged recognition of 'Palestine' by some States cannot compensate for the absence of the established criteria for statehood; and the right to self-determination must not be conflated with any claim to statehood ... The absence of a sovereign Palestinian state ... means that there is no sovereign ability to prosecute that could be delegated to the Court, and there is no 'territory of' a State (within the meaning of the Rome Statute). ${ }^{50}$

Netanyahu's response was characteristically more blunt. He told a conference of pro-settlement advocates in Jerusalem's Menachem Begin Heritage Center celebrating Pompeo's November 18 statement on the legality of Israeli settlements, that "Pompeo's declaration is the appropriate response to the scandalous decision of the International Criminal Court in The Hague to investigate the settlement enterprise in Judea and Samaria, which, brazenly, is considered a war crime." ${ }^{51}$ Pompeo gave an address to the same conference by video, where he reiterated his claim that he was only disavowing the "deeply flawed" State Department legal opinion from 1978, and "returning to a balanced and sober Reagan-era approach," which he incredulously claimed would "advance the cause of peace between Israelis and Palestinians." ${ }^{2}$ Speaking also at the conference, Defense Minister Naftali Bennett and Foreign Minister Israel Katz vowed to annex most of the West Bank. ${ }^{53}$ They may get their opportunity after the next elections, as both the Likud Party and Kahol Lavan have come out in support of President Trump's "Deal of the Century," which envis- 
ages the annexation to Israel of the Jordan Valley, and substantial parts of the West Bank. ${ }^{54}$

\section{Endnotes}

1. For the full text of Pompeo's statement on settlements see, Times of Israel, (November 19, 2019), retrieved from https://www.timesofisrael. com/full-text-of-pompeos-statement-on-settlements/.

2. Adam Garfinkle, "Pompeo and the Settlements: It's the Politics Stupid," Foreign Policy Research Institute, (December 2, 2019), retrieved from https://www.fpri.org/article/2019/12/pompeoand-the-settlements-its-the-politics-stupid/.

3. Convention (IV) Relative to the Protection of Civilian Persons in Time of War, Geneva, (August 12, 1949), retrieved from https://ihl-databases. icrc.org/applic/ihl/ihl.nsf/Article.xsp?action= openDocument\&documentld=77068F12B8857C4DC12563CD0051BDB0.

4. UN Security Council Resolution 242 (November 22, 1967), retrieved from https://unispal.un. org/DPA/DPR/unispal.nsf/0/7D35E1F729DF491C85256EE700686136.

5. Letter of the State Department Legal Advisor, Mr. Herbert J. Hansell, Concerning the Legality of Israeli Settlements in the Occupied Territories of April 21, 1978, retrieved from https://www.hlrn. org/img/documents/USSDLegalAdvisorHansell_ Itr.pdf.

6. Resolution 298 (September 25, 1971), retrieved from http://unscr.com/en/resolutions/doc/298

7. For instance, Pompeo has emphasized that the Hansell memorandum was produced by the Carter Administration and claims that the Trump Administration is returning to the "Reagan" era policy. This is questionable, however, since the Reagan Administration approved of UN resolutions confirming the applicability of the Fourth Geneva Convention to the occupied Palestinian territories. See, Marty Lederman, "Assessing the New U.S. 'View' on the Legality of Israeli Settlements in the West Bank," Just Security, (November 19, 2019), retrieved from https://www.justsecurity. org/67343/assessing-the-new-u-s-view-on-thelegality-of-israeli-settlements-in-the-west-bank/.

8. For example, see, Security Council Resolution 465, (March 1, 1980), retrieved from http://unscr. com/en/resolutions/doc/465. See also, Resolution 465 adopted during the Carter Administra- tion, which determined that "Israel's policies and practices of settling parts of its population and new immigrants" into the Palestinian territories, "including Jerusalem," was a violation of the Fourth Geneva Convention (the U.S. voted in favor of the resolution).

9. See, "Legal Consequences of the Construction of a Wall in the Occupied Palestinian Territory, Advisory Opinion," ICJ Reports, (2004), p. 136, retrieved from https://www.icj-cij.org/files/case-related/131/131-20040709-ADV-01-00-EN.pdf.

10. “Dr. Saeb Erekat on Mike Pompeo Statement on Israeli Settlements," PLO Negotiations Affairs Department, (November 18, 2019), retrieved from: https://www.nad.ps/en/media-room/press-releases/dr-saeb-erekat-mike-pompeo-statementisraeli-settlements.

11. Mike Blanchfield, "Canada's View on Israeli Settlements in West Bank Unchanged, Despite U.S. Policy Shift," Global News Canada, (November 29, 2019), retrieved from https://globalnews.ca/ news/6194046/canada-israel-west-bank-settlements/.

12. "Israeli Settlements, November 2019: UK Statement," GOV.UK, (November 21, 2019), retrieved from: https://www.gov.uk/government/ news/israeli-settlements-uk-statement

13. "General Assembly Adopts 5 Resolutions on Middle East, Including Text Urging States Not to Recognize Changes on Status of Jerusalem, Pre-1967 Borders," United Nations, (December 3, 2019), retrieved from https://www.un.org/press/ en/2019/ga12220.doc.htm.

14. According to Scott Anderson, the State Department produced a 40-page legal memorandum justifying the change of policy, but significantly the memorandum has not been published. See, Scott R. Anderson, "The Trump Administration's Worrying New Policy on Israeli Settlements," Lawfare, (November 21, 2019), retrieved from: https://www.lawfareblog.com/trump-administrations-worrying-new-policy-israeli-settlements.

15. See "Statement by President Trump on Jerusalem," The White House, (December 6, 2017), retrieved from https://www.whitehouse.gov/briefings-statements/statement-president-trump-jerusalem/.

16. Victor Kattan, "Why U.S. Recognition of Jerusalem Could Be Contrary to International Law," Journal of Palestine Studies, Vol. 47, No. 3 (2018), pp. 72-92, DOI: 10.1525/jps.2018.47.3.72.

17. "John Kerry's Full Speech on Israeli Settlements and a Two-State Solution," Time, (De- 
cember 28, 2016), retrieved from https://time. com/4619064/john-kerrys-speech-israel-transcript/.

18. See, "Peace to Prosperity: A Vision to Improve the Lives of the Palestinian and Israeli People," The White House, (January 2020), retrieved from https://www. whitehouse.gov/wpcontent/uploads/2020/01/Peace-to-Prosperity0120.pdf.

19. See, Victor Kattan, "It's Time to Take Palestine v. United States of America Seriously," Opinio Juris, (October 16, 2018), retrieved from http://opiniojuris.org/2018/10/16/its-time-to-take-palestinev-united-states-of-america-seriously/.

20. See, "The Humanitarian Impact of Settlements," OCHA, retrieved from https://www.ochaopt.org/theme/humanitarian-impact-of-settlements.

21. "Vignoble Psagot Ltd v. Ministre de l'Économie et des Finances," Grand Chamber of the European Court of Justice, (November 12, 2019), retrieved from http://curia.europa.eu/juris/document/ document.jsf?text $=\&$ docid $=220534 \&$ pageln $\mathrm{dex}=0$ \&doclang $=\mathrm{EN} \&$ mode $=\mid \mathrm{st} \& \mathrm{dir}=\& \mathrm{occ}=-$ first\&part $=1 \&$ cid $=5283217$. This followed an earlier decision by a Canadian Federal Court, which decided that wines from Jewish settlements in the West Bank should not carry labels that say they are from Israel as it would mislead consumers. See, Sasha Ingber, "Canadian Court Rules West Bank Wines Are Not a 'Product of Israel,"' National Public Radio, (July 30, 2019), retrieved from https://www.npr.org/2019/07/30/746507056/ canadian-court-rules-west-bank-wines-are-nota-product-of-israel.

22. See the documents on the ICC's website retrieved from https://www.icc-cpi.int/palestine.

23. Tovah Lazaroff, "U.S. Must Erase Legal Opinion Condemning West Bank Settlements, ZOA Says," The Jerusalem Post, (January 14, 2019), retrieved from https://www.jpost.com/Arab-Israeli-Conflict/ZOA-campaign-calls-to-erase-USopinion-condemning-West-Bank-settlements577360 .

24. Lazaroff, "U.S. Must Erase Legal Opinion Condemning West Bank Settlements, ZOA Says."

25. On the relationship between the WZO and the Government of Israel, see the documents disclosed online by the Israel Lobby Archive, retrieved from https://www.israellobby.org/ZOA/ DOJ-149-1603-ZOA/default.asp.

26. "Summary of the Opinion Concerning Unauthorized Outposts-Talya Sason, Adv.," Israel Min- istry of Foreign Affairs, (March 10, 2005), retrieved from https://www.mfa.gov.il/mfa/aboutisrael/ state/law/pages/summary\%20 of\%20opinion $\% 20$ concerning\%20unauthorized\%20utposts $\% 20-\% 20$ talya\%20sason\%20adv.aspx.

27. "The Levy Commission Report on the Legal Status of Building in Judea and Samaria," Regavim, (June 21, 2012), English translation, retrieved from https://web.archive.org/web/20150508072 813/http:/regavim.org.il/en/wp-content/uploads/2014/11/The-Levy-Commission-Reporton-the-Legal-Status-of-Building-in-Judea-andSamaria2.pdf.

28. See, the settlement division's website (in Hebrew) here: http://www.hityashvut.org.il/.

29. See, "Land Grab: Israel's Settlement Policy in the West Bank," B'TSELEM, (May 2002), retrieved from https://www.btselem.org/download/200205_land_grab_eng.pdf.

30. Report of the independent international fact-finding mission to investigate the implications of the Israeli settlements on the civil, political, economic, social and cultural rights of the Palestinian people throughout the Occupied Palestinian Territory, including East Jerusalem, UN Doc. A/HRC/22/63, (February 7, 2013), p. 6, paragraph 21.

31. "Accelerated Settlement-Building, Home Demolitions Driving Atmosphere of Despair, Hopelessness among Palestinian People, Fourth Committee Hears," United Nations, (November 7, 2017), retrieved from https://www.un.org/press/ en/2017/gaspd655.doc.htm.

32. Avi Wasksman, "Israel's Settlement Spending Rose, Even After Golan Heights Removed From the Equation," Haaretz, (December 17, 2019), retrieved from https://www.haaretz.com/israelnews/business/.premium-israel-s-settlementspending-rose-even-after-golan-heights-excluded-1.8283331.

33. See, "Israel: Law for the Regulation of Settlement in Judea and Samaria, 5777-2017," Library of Congress, retrieved from https://www.loc.gov/ law/help/israel-settlement/judea-and-samaria. php.

34. "Israel: Law for the Regulation of Settlement in Judea and Samaria, 5777-2017."

35. On the controversy over the report, see, lain Scobbie, "Justice Levy's Legal Tinsel: The Recent Israeli Report on the Status of the West Bank and Legality of the Settlements," EJIL: Talk!, (September 6, 2012), retrieved from https://www.ejiltalk. org/justice-levys-legal-tinsel-the-recent-israeli- 
report-on-the-status-of-the-west-bank-and-legality-of-the-settlements/.

36. See, "The Levy Commission Report on the Legal Status of Building in Judea and Samaria," supra note 26, p. 74 .

37. See, "Article 8(2)(b)(viii) Rome Statute," ICC, retrieved from https://www.icc-cpi.int/resource-library/documents/rs-eng.pdf.

38. Barak Ravid and Chaim Levenson, "Netanyahu Warns Cabinet: Outpost Legalization Bill Could Lead to International Probe Against Israeli Officials," Haaretz, (November 28, 2016), retrieved from https://www.haaretz.com/israel-news/.premium-netanyahu-warns-cabinet-legalizing-outpost-could-lead-to-international-probe-1.5467229.

39. Yuval Karni, Tova Tzimuki, and Moran Azulay, "Netanyahu, Bennett Reach Compromise on Regulation Bill," Ynet News, (May 12, 2016), retrieved from https://www.ynetnews.com/articles/0,7340,L-4888496,00.html.

40. See, Barak Ravid, "Behind the Scenes of Trump's Shift on Israeli Settlements," Axios, (November 20, 2019), retrieved from https://www. axios.com/israel-settlements-west-bank-legaltrump-pompeo-5c8f3a1f-e690-4281-8c49-936a 0307124c.html. On the role of the Kohelet Policy forum, see: https://en.kohelet.org.il/.

41. Ravid, "Behind the Scenes of Trump's Shift on Israeli Settlements."

42. Lahav Harkov, "Pro-settler Lobby: Apply Israeli Law in Settlement Building," The Jerusalem Post, (October 21, 2015), retrieved from https://www. jpost.com/Israel-News/Politics-And-Diplomacy/ Land-of-Israel-Caucus-relaunches-with-billstreamlining-building-in-settlements-428649.

43. See, "Prosecution Request Pursuant to Article 19(3) for a Ruling on the Court's Territorial Jurisdiction in Palestine," ICC, (December 20, 2019). This has since been removed from the ICC's website but the author has a copy.

44. "John Bolton Threatens ICC with US Sanctions," BBC News, (September 11, 2018), retrieved from https://www.bbc.com/news/world-us-canada-45474864.

45. "Prosecution Request Pursuant to Article 19(3) for a Ruling on the Court's Territorial Jurisdiction," ICC, supra note 42, pp. 85-93.

46. With regard to the establishment of settlements on private Palestinian land, the Supreme
Court only ruled in the Elon Moreh case (1979) that they were unlawful if their establishment could not be justified for a military purpose. See, Izzat Muhammad Mustafa Duweikat et al. v. Government of Israel, (October 22, 1979), English translation, available from http://www.hamoked. org/files/2010/1670_eng.pdf.

47. See, "Israeli Settlements and International Law," Israel Ministry of Foreign Affairs, (November 30, 2015), retrieved from https://mfa.gov.il/mfa/ foreignpolicy/peace/guide/pages/israeli\%20settlements\%20and\%20international\%20law.aspx.

48. See, "Prosecution Request Pursuant to Article 19(3) for a Ruling on the Court's Territorial Jurisdiction in Palestine," ICC, supra note 42, p. 111, paragraph. 220.

49. These include Daniel Reisner, a former adviser to Prime Ministers Rabin, Peres, Netanyahu, Barak and Sharon; Robbie Sabel who served as Legal Adviser in Israel's Ministry of Foreign Affairs for many years; and Yael Vias Gvirsman, who worked as Legal Adviser in Israel's Ministry of Foreign Affairs and Ministry of Justice. See, "Decision on Applications for Leave to File Observations Pursuant to Rule 103 of the Rules of Procedure and Evidence," (February 20, 2020) retrieved from https://www. icc-cpi.int/CourtRecords/CR2020_00610.PDF .

50. "The International Criminal Court's Lack of Jurisdiction over the So-called 'Situation in Palestine,' State of Israel Office of the Attorney General, (December 20, 2019), retrieved from https:// mfa.gov.il/MFA/PressRoom/2019/Documents/ ICCs\%20lack\%20of\%20jurisdiction\%20over\%20 so-called $\% 20 \%$ e $2 \% 80 \% 9$ csituation $\% 20$ in $\% 20$ Palestine\%e2\%80\%9d\%20-\%20AG.pdf, p. 2.

51. Raphael Ahren, "ICC Probe Won't Deter Israel from Expanding Settlements, Netanyahu Vows," The Times of Israel, (January 8, 2020), retrieved from https://www.timesofisrael.com/icc-probewont-deter-israel-from-expanding-settlementsnetanyahu-vows.

52. Ahren, "ICC Probe Won't Deter Israel from Expanding Settlements, Netanyahu Vows."

53. Ahren, "ICC Probe Won't Deter Israel from Expanding Settlements, Netanyahu Vows."

54. Barak Ravid, "Israeli Officials Believe U.S. May Release Peace Plan Before Election," Axios, (January 8,2020 ), retrieved from https://www.axios. com/trump-middle-east-peace-plan-israel-elections-6e65d9d4-90b4-49cc-af6d-acd8fae8188c. html. 


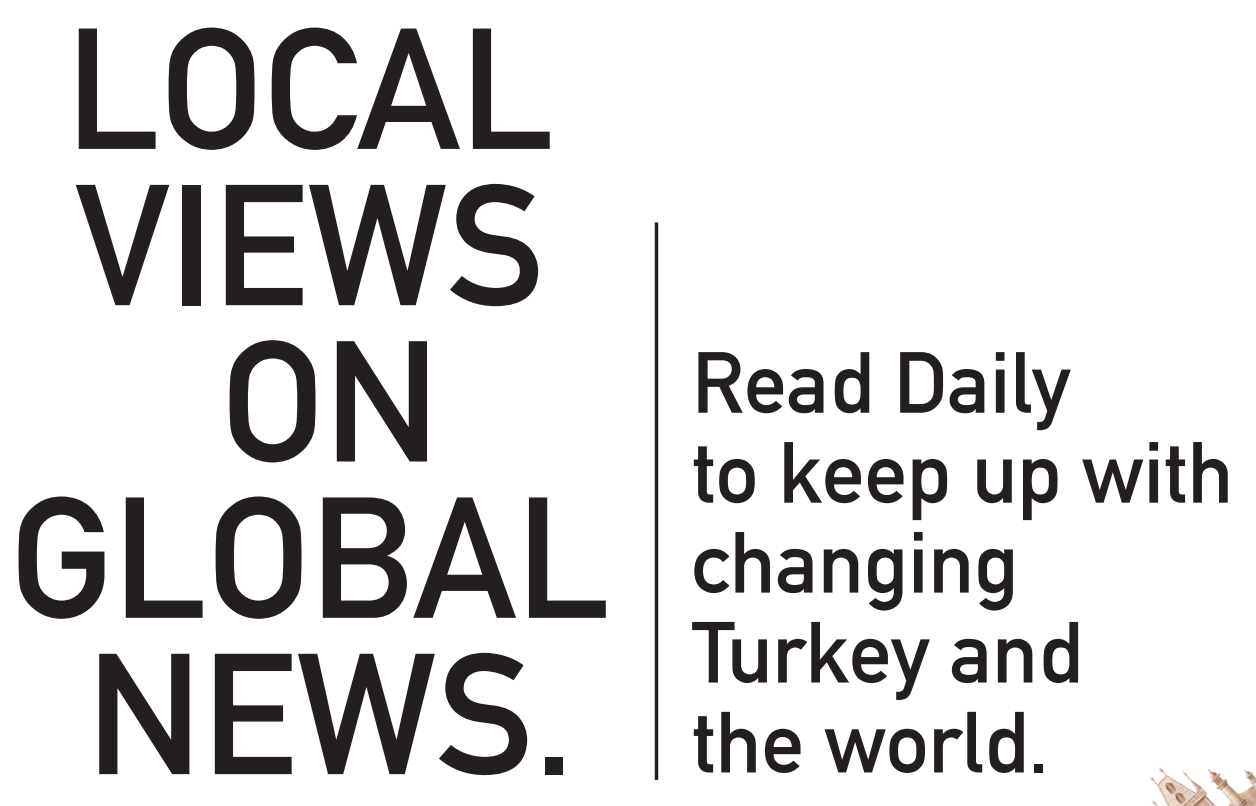

Read Daily to keep up with changing Turkey and the world.

\section{DAILY БАВAН}

